\title{
EU-China Economic Relations: Interactions and Barriers
}

\author{
Zheng $\mathrm{Lu}^{1,3}$, Tianqin $\mathrm{Yan}^{2,3} \&$ Xiang Deng ${ }^{1,3}$ \\ ${ }^{1}$ School of Economics, Sichuan University, Chengdu, China \\ ${ }^{2}$ College of Foreign Languages and Cultures, Sichuan University, Chengdu, China \\ ${ }^{3}$ Centre for European Studies, Sichuan University, Chengdu, China \\ Correspondence: Zheng Lu, School of Economics, Sichuan University, Chengdu, 610064, China. Tel: \\ 86-28-8541-3033. E-mail: zlu@scu.edu.cn
}

\author{
Received: September 2, 2014 Accepted: September 17, 2014 Online Published: November 15, 2014 \\ doi:10.5539/res.v6n4p12 URL: http://dx.doi.org/10.5539/res.v6n4p12
}

\begin{abstract}
EU-China economic interactions became more and more frequent in the past decades, nowadays EU and China are main trade partner for each other. This paper analyzed EU-China economic interactions from three dimensions: bilateral governmental interactions, trade and investment flows as well as barriers to trade and investment. Findings show that EU-China close relationship is particularly based on goods trade especially on intra-industrial trade of manufacturing industrial products, and trade imbalance is arising from trade in Machinery and Transport Equipment and Other Manufactured Goods (e.g., Clothing and clothing accessories); This paper also found that there exist a myriad of trade and investment barriers to EU-China interactions, including both tariff and non-tariff obstacles. Therefore, this paper argued that if EU and China want to handle the trade imbalance efficiently, they must improve composition of trade in goods, while essentially, it requires lessening or eliminating EU-China trade barriers which hampered trade composition improvement.
\end{abstract}

Keywords: EU-China relations, trade, trade barriers, FDI

\section{Introduction}

China's development in the past decades has attracted world-wide. As a country that has more than 1.3 billion population, its annual average economic growth is over 10\% (real GDP growth) from 1980s to 2000s. Undoubtedly, China's Reform and Opening-up policies initiated in the end of 1970s have contributed much to the economic boom particularly gains. In the third plenary session of $11^{\text {th }}$ central committee of CCP held in 1978, Chinese central government decided to quit the idea of "economy being subordinated to politics". Accordingly, China began to reform the economic system and open its gate to the outside world. Since then, promoting economic development began to be regarded as the paramount task of the central government. The Opening-up policy was firstly experimented in eastern coastal regions in 1980s, and then it was gradually applied to the entire country in early 1990s. Later, CCP proposed to partially give up the Planned Economic System and tried to build a Socialist Market Economic System in 1992. So far as the labor force is concerned, the central government and various enterprises realize that China has an obvious advantage over other countries. What is more, because of insufficient domestic demand, export-oriented strategy was considered to be the most fundamental tactic to promote economic development.

There is no denying the fact that export has become one of the three driving factors (consumption, investment and export) of China's economic growth in the past decades. Total exports and imports amounts to12.54\% of GDP, and total exports amounts to $5.97 \%$ of GDP in 1980 , and then they increased to $29.78 \%$ and $15.99 \%$ in 1990 , and $39.58 \%$ and $20.80 \%$ in 2000 . In 2006, these two percentages reached the highest points, $65.17 \%$ and $35.87 \%$. Since the global financial crisis broke out in 2007, China's exports trade was seriously affected, total exports and imports percentage of GDP and the total exports percentage of GDP reduced in recent years, but they were respectively $50.28 \%$ and $26.68 \%$ in 2010 . Moreover, government also launched many preferential policies to attract foreign investment, such as income tax exemption or reduction. Actual utilized FDI was only $\$ 3.49 \mathrm{bn}$ in 1990 , but it increased to $\$ 40.72 \mathrm{bn}$ in 2000 , and even reached $\$ 105.74 \mathrm{bn}$ in 2010 . These facts adequately prove that international economic and trade interactions are exactly very important to China's economic development.

Currently, China is the second exports economy and the third imports economy in the world. And, as the largest exporter and importer in the world, EU has been an important export destination and source of imports and FDI 
of China. In March 2004, European Union (EU) became the largest trade partner of China, and China became the second largest trade partner of EU (Dai, 2006). Actually, Since European Economic Community (EEC) and China established diplomatic relations in 1975, EU-China economic and trade relations have become much closer. EU commission once stated that as the EU and China become "Closer Partner", they also begin to shoulder "Growing Responsibilities" for each other. Nevertheless, competition from China especially in some manufacturing sectors also raised serious challenges to the EU. (EU Commission, 2006). No one can deny the fact that China's huge market is very attractive to European companies, and trading with China can help them create job opportunities and promote EU's economic growth; competition from China can impel European companies to cut cost and reinforce their comparative advantages. For example, in the area of technology innovation, EU actually can not only keep competitiveness but also benefit a lot from trading with China. Similarly, China can also gain a lot from trading with the EU including, from investment and technology transfer Therefore, it can be safely concluded that EU-China economic and trade interactions can result in reciprocal progress and mutual benefit.

Nevertheless, one of the preconditions for EU and China to maximize their benefits from trade and economic partnership is that both sides must open their markets and ensure fair competition (Lorca-Susino, 2006), in other words, they must reduce exchange cost as far as possible. But in fact, there exist a myriad of trade barriers between EU and China, especially nontariff obstacles, which invariably result in high EU-China economic exchange cost. China's market is not open entirely, and it is also reported that protectionism is on the rise in Europe (Ashton, 2009). Generally speaking, China is treated as a manufacturing economy which is based on the competitive advantage of cheap labor and land (Dai, 2006). Owing to this advantage, China is able to produce merchandises with much lower cost. But the EU doubts that Chinese government supports export through subsidy, exchange regulation and some other policies, and some industries are still not open to foreign investment. Similarly, the EU also sets up some barriers to trade and investment, and also keeps some restriction on sensitive products; the main instruments are technical barrier to trade (TBT) and anti-dumping measures (Brülhart \& Matthews, 2007).

This paper will briefly investigate the general situation of EU-China economic relations by introducing the status quo and barriers of EU-China trade and investment. The first section will introduce the bilateral governmental interactions, and the second section will analyze the status quo of EU-China trade and investment, and it will mainly focus on the industrial structure of EU-China trade. The third section will discuss some typical cases to illustrate various trade and investment barriers to EU-China. And the final part is the conclusions and remarks.

\section{EU-China Bilateral Governmental Interactions}

China and EEC established diplomatic relations in 1975, and in 1985, EEC and China signed the first trade and economic cooperation agreement, namely, the "Agreement on Trade and Economic Cooperation between European Economic Community and the People's Republic of China". What is more, the two parts also established a joint committee to manage the cooperation relationship (Council of EEC \& Government of P. R. China, 1985). Trade cooperation targets on creating favorable conditions for bilateral trade and grants each other most-favored nation treatment, such as lower customs duties and charges, simplifying regulation, procedures and formalities. This bilateral agreement continues to be the main legal framework of EU-China trade and economic relations (Griese, 2006), and it is updated on the $9^{\text {th }}$ EU-China Summit held in Helsinki in 2006. Upon signing the agreement in1985, the trade volume between EU-China increased remarkably, especially in 1990s (Note 1). In terms of statistical data, EU's exports to China was only $€ 1.9 \mathrm{bn}$ and just ranked No.24 in EU's exports partners in 1980, exports value increased to €5.8bn, and China ranked No.13 in 1990. While in 1998, the value increased to $€ 17.4 \mathrm{bn}$, and China became the fourth largest exports trade partner. On the imports side, value of EU's imports from China was only €2.0bn and China ranked No.22 in EU's imports partners in 1980, then imports value increased to $€ 10.4 \mathrm{bn}$, and China rose to No.5. In 1998, EU's imports from China reached $€ 42.0 \mathrm{bn}$ and China became the third largest imports trade partner of EU (Note 2). 
Table 1. EU-China key governmental interactions

\begin{tabular}{|c|c|}
\hline Year & Actions \\
\hline 1975 & $>$ Established diplomatic relations between China and EEC. \\
\hline 1985 & $\begin{array}{l}>\text { Agreement on Trade and Economic Cooperation between European Economic } \\
\text { Community and the People's Republic of China. }\end{array}$ \\
\hline 1998 & $\begin{array}{l}\text { EU-China Summit (annually, the } 14^{\text {th }} \text { Summit was held in Feb. 2012). } \\
\text { EU Communication [COM(1998)181] : Building a comprehensive partnership with } \\
\text { China. }\end{array}$ \\
\hline 2001 & $\begin{array}{l}>\text { EU Communication }[\mathrm{COM}(2001) 265 \text { final]: further enhancement of engagement with } \\
\text { China; China is both part of the problem and the solution to all major issues of } \\
\text { international and regional concern. } \\
>\text { Established a Comprehensive Partnership coming with the China's WTO accession. }\end{array}$ \\
\hline 2003 & $\begin{array}{l}>\text { Comprehensive Strategic Partnership. } \\
>\text { EU Commission [COM(2003)533final]: A maturing partnership-shared interests and } \\
\text { challenges in EU-China relations. }\end{array}$ \\
\hline 2006 & $\begin{array}{l}>\text { On } 9^{\text {th }} \text { EU-China Summit (Helsinki), decided to start negotiation on a PCA (EU-China } \\
\text { Partnership \& Cooperation Agreement), PCA will cover both political and economic } \\
\text { dimensions of EU-China relations. } \\
\text { And, it also involves an upgrade of Trade and Economic Cooperation Agreement } \\
\text { launched in } 1985 \text {. }\end{array}$ \\
\hline 2008 & $\begin{array}{l}>\text { High Level Economic and Trade Dialogue (HED, annually, and the } 1^{\text {st }} \text { meeting was held } \\
\text { on } 25 \text { April in Beijing). } \\
\text { HED provides a tool to address issues of mutual concern in the areas of investment, } \\
\text { market access and intellectual property rights protection, as well as other issues related } \\
\text { to trade. }\end{array}$ \\
\hline
\end{tabular}

Source: Author's depiction.

In 1990s, there were some remarkable changes in China's economy reform and development, for instance, China started to transform a centrally-planned and largely closed economy into an increasingly market-driven economy after 1992 when CCP proposed and tried to build a Socialist Market Economic System (EU Commission, 1998). The EU acknowledges that China has made considerable efforts to reform and develop market economy, and China is more and more responsible in foreign affairs. Meanwhile, it is not sure whether China can continue to reform in post-Deng Xiaoping era and handle the shock from Asian financial crisis exploded in 1997. In order to amend its approach to China based on new assessments (Smith \& Xie, 2010), the EU commission made a new policy, namely "Comprehensive Partnership with China" in March 1998 (Note 3). The new policy mainly aimed at engaging China further in the international community through an upgraded political dialogue, supporting China's transition to an open society, and integrating China further in the world economy by promoting China more fully into the world trading system and supporting China's economic and social reform (EU Commission, 1998). Yet On 2 April 1998, the $1^{\text {st }}$ EU-China Summit was held in London, and it was pinned down as an interaction and communication mechanism which is held annually. This summit offers a forum for the two parts to discuss bilateral political and economic interactions as well as some other issues of common concern.

To deal with China's forthcoming accession to WTO, EU made a new policy_-"Strategy towards China: Implementation of the 1998 Communication and Future Steps for a More Effective EU Policy" On 15 May 2001, (EU Commission, 2001). This strategy includes two parts, the first one evaluates the implementation outcomes of building comprehensive partnership with China, and the second one is a supplement to the old policies based on new situation. With China's accession to WTO on 11 December 2001, the comprehensive partnership was formally established. Two years later, EU Commission issued the policy paper-"A Maturing Partnership-shared Interests and Challenges in EU-China relations", which states that "EU and China have an ever-greater interest to work together as strategic partner to safeguard and promote sustainable development, peace and stability" (EU Commission, 2003). This approach focuses on support sectoral cooperation through strengthening or launching 
sectoral dialogues. On the $9^{\text {th }}$ EU-China Summit (Helsinki, 9 September, 2006), the EU and China decided to open negotiations on a PCA (EU-China Partnership \& Cooperation Agreement); PCA will cover both political and economic dimension of EU-China relations. The $9^{\text {th }}$ EU-China Summit also involves an upgrade of "Trade and Economic Cooperation Agreement" launched in 1985. In 2008, the First EU-China High Level Economic and Trade Dialogue (HED) was held in Beijing. HED provides a tool to address issues of mutual concern in the areas of investment, market access and intellectual property rights protection, as well as other trade issues

\section{EU-China Trade and Investment Interactions}

\subsection{EU-China Goods Trade Flows}

The historical development of EU-China relations shows that both EU and China treat each other as an important economic partner, and they are attempting to build a high level partnership through frequent and stable negotiations or dialogue mechanisms. Frequent dialogues and political interactions have greatly helped to improve EU-China trade relations. As mentioned above, China has been the No.1 export partner and No.2 import partner of EU, the trade volume has increased over 4 times in the past ten years. There is no doubt that both the EU and China have benefited a lot from bilateral trade. In 1999, EU-27 exported $€ 19.66$ bn goods to China and imported $€ 52.60 \mathrm{bn}$ goods from China. While by 2010, EU's exports to China increased to $€ 113.25 \mathrm{bn}$, and imports from China rose to $€ 282.51 \mathrm{bn}$.

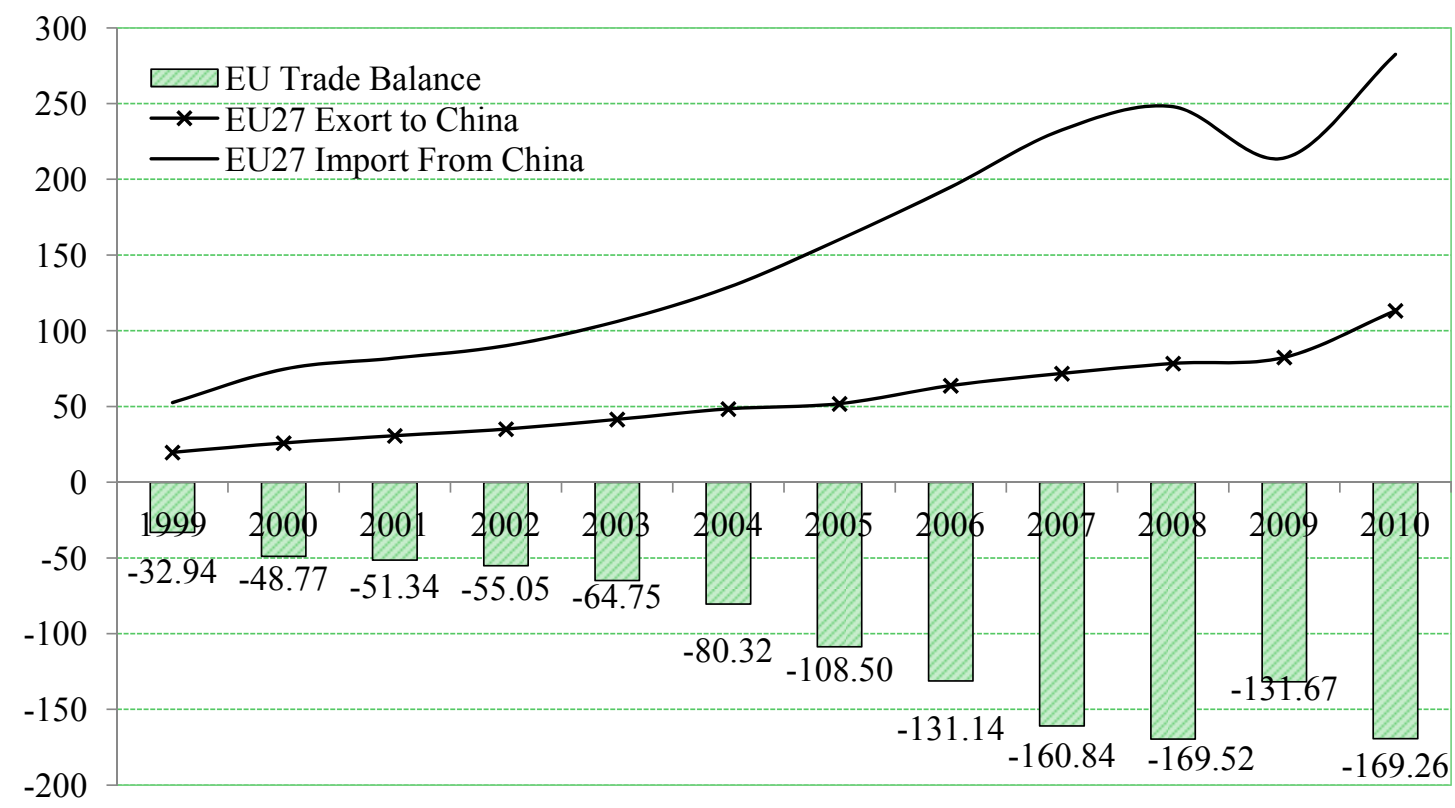

Figure 1. EU-China goods trade trends (Billion Euro, 1999-2010)

Source: EUROSTAT.

However, as the largest trading partner of China, the EU has been troubled by the huge trade deficit with China in a long time. With China's accession to WTO, EU cancelled many imports limitation in line with the principle of WTO. Consequently, imports from China increased sharply due to China's advantages of production cost. As a result, EU's trade deficit with China rose by a large margin, from only €32.94bn in 1999 to $€ 169.26 \mathrm{bn}$ in 2010(Table 1). In terms of a rough product classification, EU's trade deficit with China particularly resulted from importing Machinery, Transport Equipment and other manufactured products (e.g. textile, clothing, iron and steel, etc.). Except for food, drinks and tobacco, balance is maintained in other goods trade. In 2000, deficit caused by the trade of Machinery reached $€ 11.21 \mathrm{bn}$, and that caused by Transport Equipment and Other Manufactured Goods were $€ 35.78 \mathrm{bn}$. By the end of 2010 , they reached $€ 75.37 \mathrm{bn}$ and $€ 99.81 \mathrm{bn}$ respectively. Thus the total deficit summed up to $€ 175.18 \mathrm{bn}$ (Table 2). The main contributors to 2010 EU's trade deficit with China are (Table A2): Telecommunication, sound, TV, video ( $€ 35.77 \mathrm{bn})$; Office machines and Computers $(€ 39.21 \mathrm{bn})$; Electrical machinery (€29.36bn); Clothing and clothing accessories (€30.11bn); and other miscellaneous manufactured articles (€23.38bn). 
Table 2. Product breakdown of EU trade in goods with China (Billion Euro)

\begin{tabular}{lccccccccc}
\hline \multirow{2}{*}{ Industries } & \multicolumn{3}{c}{ EU Export to China } & \multicolumn{3}{c}{ EU Import from China } & \multicolumn{3}{c}{ Balance } \\
\cline { 2 - 10 } & 2000 & 2005 & 2010 & 2000 & 2005 & 2010 & 2000 & 2005 & 2010 \\
\hline $\begin{array}{l}\text { Food, } \\
\text { Drinks and }\end{array}$ & 0.439 & 0.797 & 2.239 & 1.525 & 2.267 & 4.004 & -1.086 & -1.47 & -1.765 \\
$\begin{array}{l}\text { Tobacco } \\
\text { Raw }\end{array}$ & & & & & & & & & \\
$\begin{array}{l}\text { Materials } \\
\text { Energy }\end{array}$ & 1.417 & 3.297 & 7.702 & 1.571 & 2.411 & 2.690 & -0.154 & 0.886 & 5.012 \\
$\begin{array}{l}\text { Products } \\
\text { Chemicals }\end{array}$ & 0.162 & 0.064 & 0.742 & 0.402 & 0.731 & 0.304 & -0.24 & -0.667 & 0.438 \\
$\begin{array}{l}\text { Machinery } \\
\text { and }\end{array}$ & 2.421 & 5.180 & 12.661 & 2.805 & 5.178 & 11.014 & -0.384 & 0.002 & 1.647 \\
$\begin{array}{l}\text { Transport } \\
\text { Equipment }\end{array}$ & 16.528 & 31.002 & 69.612 & 27.739 & 75.082 & 144.989 & -11.211 & -44.08 & -75.377 \\
$\begin{array}{l}\text { Other } \\
\text { Manufactu } \\
\text { red Goods }\end{array}$ & 4.285 & 10.268 & 18.510 & 40.066 & 74.052 & 118.317 & -35.781 & -63.784 & -99.807 \\
$\begin{array}{l}\text { Non-classi } \\
\text { fying }\end{array}$ & 0.611 & 1.217 & 1.806 & 0.524 & 0.606 & 1.213 & 0.807 & 0.611 & 0.593 \\
$\begin{array}{l}\text { Goods } \\
\text { Total }\end{array}$ & 25.863 & 51.825 & 113.272 & 74.632 & 160.327 & 282.531 & -48.769 & -108.502 & -169.259 \\
\hline
\end{tabular}

Source: EU Trade Yearbook 2011(EUSTAT, 2011).

It should be acknowledged that EU-China trade is mainly based on the intra-industrial trade of some manufactured industrial products, i.e. Machinery and Transport Equipment as well as Other Manufactured Goods. Actually, both China and the EU have comparative advantages in these products. Statistical data show that the share of Chemicals, Manufactured goods classified by material, Machinery and Transport Equipment and Miscellaneous Manufactured Articles in total exports of EU-27 reached 83\% in 2010, of which Machinery and Transport Equipment shared $42.4 \%$, but the share of those products in China reached $94.61 \%$, of which Machinery and Transport Equipment shared $49.13 \%$ (Table A1). As far as EU-China goods trade is concerned, it can be found that EU and China also exchange manufactured industrial products. In 2010, EU-27 exported $€ 69.61 \mathrm{bn}$ Machinery and Transport Equipment to China, which accounted for $61.45 \%$ in total exports to China. And China exported $€ 144.99 \mathrm{bn}$ Machinery and Transport Equipment to EU, which accounted for $51.32 \%$ in total exports to EU. In sum, the value of Machinery, Transport Equipment and Other Manufactured Goods exported by EU-27 to China amounted to $€ 88.12$ bn with a share of $77.80 \%$; Meanwhile, China exported $€ 263.31$ to EU in 2010, and the share reached 93.20\%; imports products of EU and China from each other also reflected the same conclusion (Table 2). To some extent, these evidences exactly proved that EU-China trade takes place particularly on intra-industries, which conforms to the world trade trend proved by Krugman's New Trade Theory. This conclusion is also proved by Beneyto et al. (2011, p. 17), whose analysis used a quantitative method based on EU's member state trade with China.

\subsection{EU-China Services Trade and Capital Flows}

Other dimensions related to economic relations are services trade and capital mobility. Compared with the trade in goods, the volume of services trade and the amount of FDI flows between EU and China are much smaller. In 2010, EU-China commercial services export trade volume was only $€ 22.3 \mathrm{bn}$, and the balance was positive. The amount of FDI flows from the EU to China was $€ 6.5 \mathrm{bn}$ in 2009, only accounting for $5.39 \%$ of China's total inward FDI, yet the accumulative value was $€ 63.6 \mathrm{bn}$, sharing $6.71 \%$ of the total. China's inward FDI are mainly from oversea Chinese, for example over half of FDI are from Hong Kong, Taiwan and Singapore, and the total share amounts to $54.81 \%$ in 2009. Some free ports, for example, British Virgin Islands (BVI), are also the main sources of China's FDI. In 2009, 12.01\% of China's inward FDI is from BVI (Note 4). Actually, BVI has many companies which are run by Chinese businessmen or institutions. It is estimated that more than $25 \%$ of the companies registered in BVI have connections with China. Some Mainland Chinese are willing to set up companies in international free ports, because on the one hand, it is easy to register; on the other hand, they can enjoy tax avoidance. If these Chinese go back to invest in China, they can enjoy the preferential policy which 
aims at encouraging FDI (such as income tax exemption or reduction; as regards to investing in key industries of strategic importance, income tax will be exempted in the first three years and half income tax will be levied in the subsequent two years). Anyway, goods trade is the leading role of EU-China economic and trade relations rather than capital mobility and services trade.

Table 3. EU-China economic and trade indicators (Billion Euro)

\begin{tabular}{|c|c|c|c|c|c|c|c|c|c|}
\hline \multirow{2}{*}{ Dimensions } & \multicolumn{3}{|c|}{ EU27 to China } & \multicolumn{3}{|c|}{ China to EU27 } & \multicolumn{3}{|c|}{ Balance } \\
\hline & 2008 & 2009 & 2010 & 2008 & 2009 & 2010 & 2008 & 2009 & 2010 \\
\hline Trade in Goods & 78.4 & 82.4 & 113.3 & 247.9 & 214.1 & 282.5 & -169.5 & -131.8 & -169.3 \\
\hline Trade in services & 20.2 & 19.1 & 22.3 & 15.2 & 13.6 & 16.3 & 5.0 & 5.4 & 6.0 \\
\hline Flows & 6.9 & 6.5 & 7.1 & -0.4 & 0.1 & 0.7 & 6.9 & 6.5 & 6.4 \\
\hline Stocks & 54.7 & 63.6 & 75.1 & 5.6 & 5.6 & 6.7 & 49.1 & 57.9 & 68.4 \\
\hline
\end{tabular}

Notes: Services is commercial services; Source: EUROSTAT (NewCronos).

\section{Trade and Investment Barriers between the $\mathbf{E}$ and China}

\subsection{Attitudes Determine Actions}

China's market is important to the EU's products, and the EU expects to gain benefits from China's economic boom. Generally speaking, the EU's attitude towards economic relation with China tends to be more liberal. But in fact, the EU's decision is based on the agreement of member states, and those states who play a leading role in the $\mathrm{EU}$ are important decision makers.

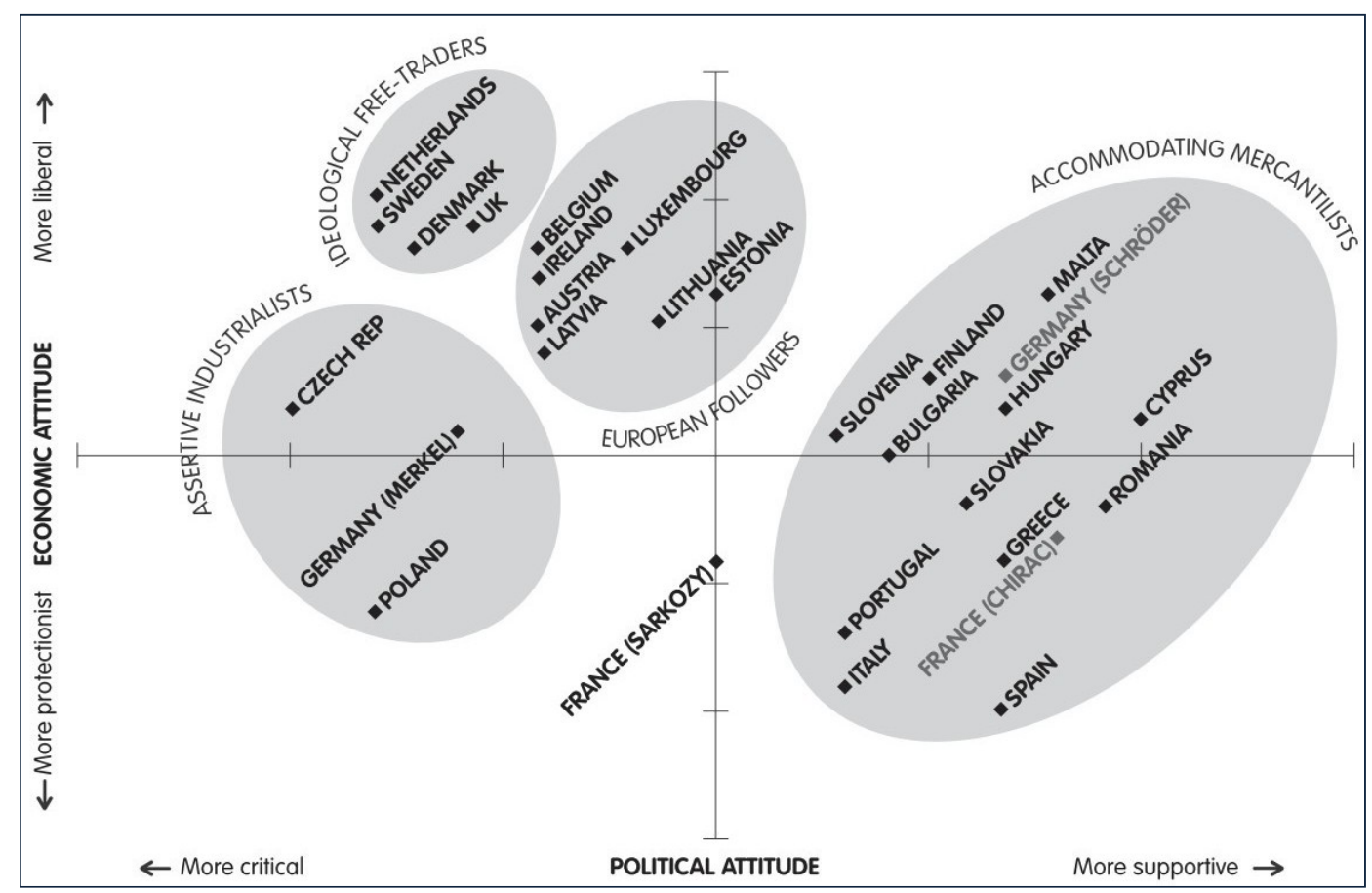

Figure 2. EU member states attitudes to China

Sources: Fox \& Godement (2009, p. 4).

The EU member states can be divided into four types in terms of their attitudes to China (Fox \& Godement, 2009, p. 4): Type-A can be classified as assertive industrialists, such as Czech, Poland and Germany. This group of countries tends to exert influence on China in both economic and politic dimensions, and support using 
protective measures to pressure China into reducing trade barriers; Type-B can be called ideological free-traders, which include Netherlands, Sweden Denmark and UK. When requiring China to reduce trade barriers, they tend to impose pressure on China in politics rather than restrict trade directly, and they also claim that the EU should focus on benefiting from China's growth rather than on the threat imposed by Chinese cheap products. Type-C can be labeled as accommodating mercantilists, which include Finland, Italy, Spain, Greece, and Romania, etc. This is the largest group, and members in which claim that keeping good political relationship with China will create commercial benefits, and economic considerations must be the priority in EU-China relations; but they also treat protective measures as a useful tool. The members in the last group are European followers, and they don't think their relationship with China is essential in their foreign policies. So this type of states prefers to follow EU's policies rather than making independent foreign policies toward China. According to the idea of Fox and Godement (2009), most EU active member states hold that both political dialogues and protective measures are useful trade instruments. Therefore, if more conservative states play a leading role in the process of decision making, the common external trade policy could be more protective, especially when the EU faces a huge trade deficit with China. As a matter of fact, the EU maintains common protective measures against external countries, which include both tariffs and non-tariff barriers (Mullally, O’Brien \& Stephenson, 2005, p. 8).

To some degree, China can be regarded as the best case of openness and growth in the past decades due to its positive reform in economic system, pricing mechanism and trade system, etc. What is more, Chinese central government has implemented effective policies to encourage export to develop economy (Lardy, 2003). The EU's huge market is very attractive to Chinese entrepreneurs, and China wants to maximize its benefits in the EU's market while protects its domestic industries. Fox and Godement (2009) describe China's approach to the EU's market as follows:

"To secure these goals, China has developed three basic tactics in its approach to the EU. First, it takes advantage of the mismatch between its own centrally controlled systems and the EU's open market and government to exploit opportunities in Europe while protecting its own economy with industrial policies, restricted access and opaque procedures. Second, China channels EU pressure on specific issues by accepting formal dialogues and then turning them into inconclusive talking shops. Third, China exploits the divisions between Member States."

$$
\text { —John Fox \& François Godement (2009, p. 8) }
$$

Notably China's attitude to the EU's market is unambiguous. It treats EU as an important export market and wants to gain a lot from trade and investment. Meanwhile, it also tries to keep its comparative advantages through making use of various protective measures. For instance, in order to enjoy the preferential supports from EU and urge the EU to eliminate trade restrictions imposed on central-controlled economy countries, China often reiterates that is just an underdeveloped country with a market economy.

Therefore, it is no wonder why there still exist some tariff and non-tariff trade barriers between the EU and China. The following part of this paper will focus on the main obvious obstacles to EU-China bilateral trade and investment, i.e. tariff barriers, non-tariff barriers and investment barriers (Table 4). 
Table 4. Trade and investment barriers between EU and China

\begin{tabular}{|c|c|c|}
\hline Types & EU Actions on China's Goods/Capital & China Actions on EU Goods/Capital \\
\hline $\begin{array}{l}\text { Tariff } \\
\text { Barriers }\end{array}$ & $\begin{array}{l}\text { Discriminatory Duties } \\
\text { Anti-dumping Duties } \\
\text { Anti-subsidy Duties }\end{array}$ & $\begin{array}{l}\text { Relatively higher tariffs rate(under WTO rules) } \\
\text { Anti-dumping Duties (e.g. on potato starch } \\
\text { starting in February 2007; on X-Ray security } \\
\text { equipment starting in Jan. 2011) }\end{array}$ \\
\hline & $\begin{array}{l}\text { Technical Barriers: Green or } \\
\text { environmental protection standards } \\
\text { (e.g. Foods, Textile, electronic } \\
\text { equipment such as Freezer, } \\
\text { Air-conditions) } \\
\text { Export Restrictions(especially on } \\
\text { Hi-tech products in order to keep } \\
\text { intellectual property and keep } \\
\text { advantages in the future) } \\
\text { Arms sale ban (due to political } \\
\text { considerations) } \\
\text { Dumping } \\
\text { Subsidies (especially on agricultural } \\
\text { products) } \\
\text { Anti-dumping investigations } \\
\text { Anti-subsidy investigations }\end{array}$ & $\begin{array}{l}\text { Subsidies and Exports Tax Rebates } \\
\text { Quotas and License Regulation } \\
\text { Non-transparent Trade Rules } \\
\text { Exchange regulation } \\
\text { Anti-dumping investigations } \\
\text { Anti-subsidy investigations (on potato starch in } \\
\text { 2011, this is the first time to do an anti-subsidy } \\
\text { investigation on EU products ) } \\
\text { Dumping (especially currency dumping and } \\
\text { social dumping) }\end{array}$ \\
\hline $\begin{array}{l}\text { Capital } \\
\text { Mobility } \\
\text { Barriers }\end{array}$ & $\begin{array}{l}\text { Foreign Investment Restrictions and } \\
\text { National Security Review on foreign } \\
\text { investors' merger actions. [e.g. U.K. } \\
\text { (Enterprise Act 2002, Chapter 2), } \\
\text { France(Article 30 of Law No. } \\
\text { 2004-1343, Dec. 2004) and Germany } \\
\text { (German Foreign Trade Act, 2009)] }\end{array}$ & $\begin{array}{l}\text { Foreign Investment Regulation (Guidance } \\
\text { Catalogue, Regulations) and National Security } \\
\text { Review on foreign investors merger actions } \\
\text { (launched in Feb. 2011) } \\
\text { Non-transparent regulations }\end{array}$ \\
\hline
\end{tabular}

Source: Author's depiction.

\subsection{Tariff Barriers}

Owing to economic globalization, every country has realized the importance of free trade. Both developed and developing countries have been reducing their import tariff rate in recent decades, thus tariff barriers will no longer be a key obstacle to free trade. For instance, EU-15 average tariff rate of import goods from external countries was reduced to $1.54 \%$ by 2002 (Global Britain, 2004). Actually, China has begun to reduce import tariff rate since its implementation of opening-up policy, and it dropped sharply in 1990s for the sake of accession to WTO. The average import tariff rate was more than $50 \%$ in 1982, and it reduced to $40 \%$ in 1993 . But in 2001, it even dropped to $15.3 \%$ (Lardy, 2003; SCIO, 2011). After its accession to WTO, China continued to reduce the tariff rate in the light of the commitment, and the average tariff rate decreased to $9.9 \%$ in 2005 and $9.8 \%$ in 2010 (SCIO, 2011).

Therefore, Ashton (2009) argued that the main obstacles to EU-China trade relations are not those common tariff barriers but those non-tariffs ones, such as various rules and standards. However, tariff barriers still impede EU-China trade relationship, being treated as a useful instrument by both the EU and China. In general, the EU imposes a higher tariff on basic goods (such as foods and textile, in which developing countries have an advantage) from developing countries than on similar products from developed countries. Mullally, O'Brien \& Stephenson (2005) found that rich countries(GDP per capita is more than $£ 15000$ a year) just faced an average $1.6 \%$ tariff imposed by EU, and middle income countries were imposed an average $2.9 \%$ tariff; while poor countries(GDP per capita is less than $£ 5000$ a year) were imposed the highest tariff rate, $5 \%$ on average. Obviously, as a middle income country, China suffers a lot from such discriminatory duties.

What is more, the EU often levies anti-dumping duties on products imported from China. Taking the anti-dumping duty on China's ceramic tiles as an example, after one year investigation (from April 2009 to 
March 2010), EU decided to impose a provisional anti-dumping duty on ceramic tiles originating imported from China, which incredibly reached 73\%(EU Commission, 2011a). On 12 September, EU issued a definitive anti-dumping duty rate, and the highest one reached 69.7\% (EU Council, 2011a). The EU stated that China's ceramic tiles products were sold at a lower price in the EU than that in China domestic market, which had a great impact on EU's similar industries. Nevertheless, a research report stated that export prices from China are highly differentiated, and most of Chinese exporters were sold at a higher price than that set by those companies of many EU member states, and China's products only shared 6.5\% in the EU market, while EU producers shared 90\%. Thus EU's anti-dumping measures are inappropriate (Kasteng, 2012).

In addition, the EU also imposes anti-subsidy duties on products imported from China. For instance, on 6 May 2011, EU commission published the first anti-subsidy tariffs against imports from China after 15 month investigation. EU stated that Chinese government subsidized coated fine paper industry by giving cheap loans, cheap land and some preferential tax policies, which are illegal under WTO rules. Therefore, the EU decided to impose anti-subsidy duties on coated fine paper imported from China with duties ranging from $4 \%$ to $12 \%$ (EU Council, 2011b). At the same time, EU also decided to impose anti-dumping duties on coated fine paper with duties ranging from $20 \%$ to $39.1 \%$ (EU Council, 2011c). As a matter of fact, the EU imposes both anti-dumping and anti-subsidy duties on the same product (coated fine paper) imported from China. Of course, the EU's action caused a protest from China, and Chinese government argued that imposing both anti-dumping and anti-subsidy duties on the same product is a double-relief-measure to EU industry and it goes against the WTO rules.

In response to the EU's actions, Chinese government also imposed anti-dumping duties and anti-subsidy duties on some products imported from the EU. For example, on 6 February 2007, China started to impose anti-dumping duties on potato starch imported from the EU, which might last 5 years. And on 23 January 2011, Chinese government decided to impose anti-dumping duties on X-Ray security equipments imported from the EU with duties ranging from $33.5 \%$ to $71.8 \%$. On 16 September 2011 , China decided to impose anti-subsidy duty on potato starch from the EU with a duty ranging from $7.5 \%$ to $12.4 \%$; it is the first time for China to impose anti-subsidy duty on EU products. In fact, on 19 April 2011, China has begun to impose anti-dumping duty on the same products from the EU with duty ranging from $12.6 \%$ to $56.7 \%$. Moreover, as mentioned above, China's import tariff rate is still relatively high; although it will continue to be reduced to fulfill the commitment to WTO rules, it can still be treated as a tariff barriers to trade.

To sum up, although there are some other kinds of anti-dumping measures, such as warranting deposit, price commitment during the investigation, some rules and standards, the EU and China still treat imposing duties as an important remedial measure to either protect domestic industries or to revenge each other's anti-dumping or anti-subsidy duties. Therefore, tariffs, including normal duty and anti-dumping and anti-subsidy duties are still common barriers to EU-China trade, which cause great loss of profit for consumers.

\subsection{Non-Tariff Barriers}

In general, non-tariff barriers refer to import quotas, subsidies, rules, standards, regulations etc., which are popular means used by a country or a common market to protect domestic industries. Without exception, both the EU and China sometimes also resort to non-tariff barriers do deal with problems in trade and investment.

Subsidy is often exploited by the EU in agriculture in the framework of Common Agricultural Policy (CAP). CAP aims at promoting European agriculture development and making it more productive and stable by means of direct payment, market price intervention, and production quotas, etc. The EU budgets a lot annually for agricultural development. For example, it covers approximately $90 \%$ of EU's agricultural output, and about half of the EU's budget was set for agriculture in 2001 (Wickman, 2003, p. 3), which accounts for about $46 \%$ and $47 \%$ of all community expenditure in 2005 and 2006 (National Audit Office, 2008). OECD's report indicated that 35\% of EU farmers' revenue was from government's subsidies in 2003, while the figure of Australian and New Zealand was only $5 \%$ (von Reppert-Bismarch, 2004).

In the new framework, CAP spending share of the total EU budget will decrease to 32\% in 2013 (EUROPA, 2007). Although CAP expenditure is being cut down, it doesn't mean that direct subsidy will be cancelled. According to "CAP towards 2020", direct subsidy will still be used to support agriculture producers who "face very economic and natural conditions across the EU which advocates for an equitable distribution of direct aids" (EU Commission, 2010). There is no doubt, direct subsidizing to farmers results in complaints from both EU consumers and foreign countries. For the food in EU market is $80 \%$ to $100 \%$ higher than that in a free-market, and because of the high import tariff and export subsidies of the EU, the agriculture sector of developing countries was negatively affected (Wickman, 2003, p. 3). What is more, some scholars hold that CAP subsidies actually failed to protect farmers' interest. In fact, their income has been reduced by $70 \%$ from 1995 to 2000; the 
main beneficiaries are input suppliers and big landowners (Mullally, O’Brien, \& Stephenson, 2005, p. 11).

Another frequently-used non-tariff measure by the EU is technical barriers to trade (TBT), which are various measures used by the EU to regulate the market, to protect consumers and environment, or to preserve resources. TBT can be classified into two types: one is imposed by governments, and the other is imposed by non-governmental organizations (Brenton, Sheehy \& Vancauteren, 2001; Brülhart \& Matthews, 2007). This paper just focuses on the former type employed by the EU. In recent years, EU commission and council have laid down many directives or standards, which are primarily related to health, safety and environment protection. For example, "Registration, Evaluation, Authorisation and Restriction of Chemicals" (REACH) was issued in 2006, providing the framework for chemical industry to protect environment and human health. This regulation requires all foreign exporters to comply with the technical standards. Although REACH regulation of the EU is good for protecting human health and environment, it may have some negative impact on third countries trading with the EU in a short term. If they cannot come up with good solutions, their export costs will increase, which will hit the related industries in third countries, especially in the developing countries whose technical level and test conditions are very poor. Therefore, if there is no differentiated treatment for different countries, the negative impacts of REACH on developing countries would much stronger than those on developed countries.

Table 5. Recent directives of EU technical barriers to trade

\begin{tabular}{|c|c|}
\hline Codes & Subjects \\
\hline DIRECTIVE & "On End-of Life Vehicles": Prohibits the use of lead, mercury, cadmium or \\
\hline 2000/53/EC & hexavalent chromium in materials and components of vehicles. \\
\hline DIRECTIVE & "On the Restriction of the Use of Certain Hazardous Substances in Electrical \\
\hline 2002/95/EC & and Electronic Equipment" \\
\hline EN 13869:2002 & $\begin{array}{l}\text { "Lighters-Child-resistance for Lighters-Safety Requirements and Test } \\
\text { Methods" }\end{array}$ \\
\hline DIRECTIVE & "On the Approximation of the Laws of the Member States Relating to \\
\hline 2004/108/EC & $\begin{array}{l}\text { Electromagnetic Compatibility and Repealing Directive 89/336/EEC" } \\
\text { "Establishing a Framework for the Setting of Ecodesign Requirements for }\end{array}$ \\
\hline DIRECTIVE & Energy-using Products and Amending Council Directive 92/42/EEC and \\
\hline 2005/32/EC & $\begin{array}{l}\text { Directives } 96 / 57 / \mathrm{EC} \text { and } 2000 / 55 / \mathrm{EC} \text { of the European Parliament and of the } \\
\text { Council" }\end{array}$ \\
\hline $\begin{array}{l}\text { DIRECTIVE } \\
\text { 2005/84/EC }\end{array}$ & $\begin{array}{l}\text { "Amending for the 22nd Time Council Directive } 76 / 769 / \mathrm{EEC} \text { on the } \\
\text { Approximation of the Laws, Regulations and Administrative Provisions of } \\
\text { the Member States Relating to Restrictions on the Marketing and Use of } \\
\text { Certain Dangerous Substances and Preparations (Phthalates in Toys and } \\
\text { Childcare Articles)" }\end{array}$ \\
\hline $\begin{array}{l}\text { REGULATION(EC) } \\
\text { No } 1907 / 2006\end{array}$ & $\begin{array}{l}\text { "Concerning the Registration, Evaluation, Authorisation and Restriction } \\
\text { of Chemicals (REACH), Establishing a European Chemicals Agency, } \\
\text { Amending Directive 1999/45/EC and Repealing Council Regulation (EEC) } \\
\text { No 793/93 and Commission Regulation (EC) No 1488/94 as well as Council } \\
\text { Directive 76/769/EEC and Commission Directives 91/155/EEC, 93/67/EEC, } \\
\text { 93/105/EC and 2000/21/EC" }\end{array}$ \\
\hline
\end{tabular}

Notes. these directives or standards are often amended and updated according to current status, here updated versions are not listed; Source: Collected by Author.

For China, the EU's export restriction on high-tech products and arm sale embargo is a long-term trade barrier. EU Council laid out its first export regulation on dual-use items and technology in 2000(EU Council, 2000a, $2000 \mathrm{~b}, 2000 \mathrm{c}$ ), and the controlled-dual-use goods listed can be classified into ten categories(EU Council, 2000a), i.e. Nuclear Materials, Facilities and Equipment(C0), Materials, Chemicals, "Microorganisms" \& "Toxins" (C1), Materials Processing(C2), Electronics(Category 3), Computers(C4), Telecommunications and "Information Security"(C5), Sensors and Lasers(C6), Navigation and Avionics(C7), Marine(C8), Propulsion as well as Space Vehicles and Related Equipment(C9). Every key category can be further divided into five sub-types, i.e. System, Equipment and Components(A), Test, Inspection and Production Equipment(B), Materials(C), Software(D) as well as Technology(E). By formulating such exports regulations, the EU aims at protecting intellectual property rights and keeping comparative advantages in technology, while it is not conducive to developing countries that 
badly need advanced technology to develop their industries. Compared with technology exports control, EU's considerations of arm sale embargo against China is based on political issues. The arms embargo against China was initiated in 1989 in response to Chinese pro-democracy movement. The EU holds that there still exist human rights abuse and potential security problems in China; so the arm embargo should not be lifted nowadays. However, in recent years some EU member states begin to consider whether to lift arms embargo, but they confront serious pressure from US and Japan (van der Putten, 2009).

Traditionally, China attaches great importance to promoting the development of domestic industries, which is embodied in various five-year plans, such as the Five-year Plan of national economic and social development, the Five-year Plan of sectoral development as well as the Five-year Plan of various industries. China's central and local governments tend to offer subsidies to some enterprises in order to reduce operation cost. For example, if some high and new technology industries are thought to be of strategic importance by the central government, various special subsidies will be offered to them, such as loan interest subsidy, technology update and innovation subsidy, talent subsidy, etc. China set up an export tax rebate (ETR) system in 1985 in order to boost exports trade, which includes VAT (Value Added Tax) drawback and consumption tax drawback. Thanks to China's accession to WTO and the export growth, the total value of ETR grows very fast. The figure was about $\$ 7.57 \mathrm{bn}$ in 1999, and increased to $\$ 94.96 \mathrm{bn}$ in 2009. ETR rate has been adjusted several times, and currently it range from $5 \%$ to $17 \%$. After the occurrence of global financial crisis, China made another adjustment in 2009. Accordingly, the rebate rates of some products have been increased. For instance, TV transmitting equipment and sewing machine rose to $17 \%$ some agricultural processing products and electromechanical products rose to $15 \%$, Corn starch and alcohol rose to $5 \%$.

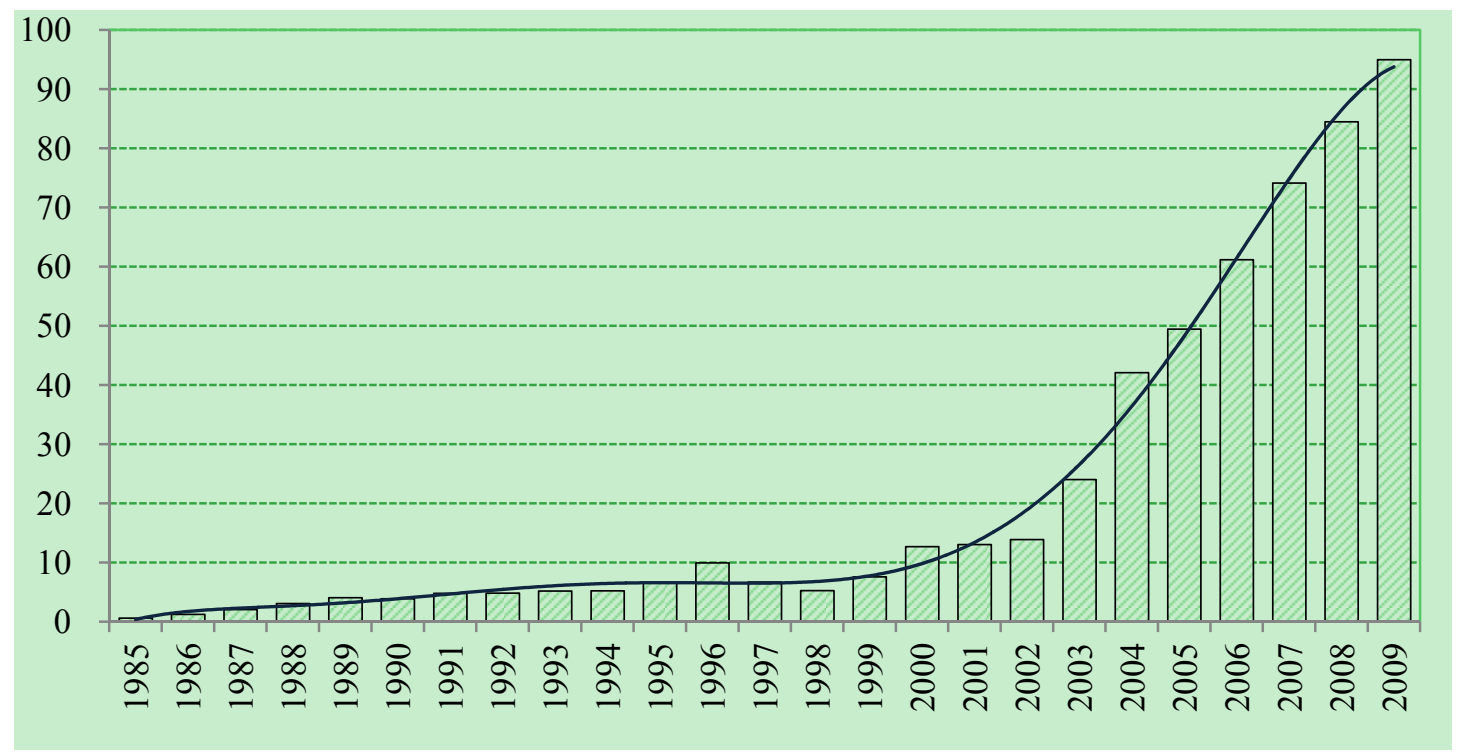

Figure 3. China's exports tax rebates (Billion US Dollars, 1985-2009)

Notes. transforming Renminbi to US dollar based on period average exchange rate; Source: exports tax rebates value derived from Finance Yearbook of China 2010(Ministry of Finance, 2010), exchange rate derived from China Statistical Yearbook 2011(National Bureau of Statistics, 2011).

Except for some observable subsidies, there are also some hidden subsidizing actions which have positive effect on export. For instance(Box 1), in April 2012, South Korea company, SAMSUNG decided to build a production base of Nand Flash, where core processors for iPhone and iPad will be produced. Three local governments competed against each other to win the project, for it can help to create job opportunities and increase the local GDP. Finally this production base was built in Xi'an, because the local government of Shanxi Province offered SAMSUNG some very attractive preferential policies which include not only direct investment subsidy, income tax exemption, but also free land provision and operating cost subsidies. What is more, the local government committed to build required transportation means to the plant. Actually, the products of this plant are just the sub-units of iPhone and iPad, and the final products will be produced by another assembly foundry of APPLE INC., FOXCONN which locates in Chengdu, Sichuan province (Chengdu is a city close to Xi'an, Chengdu local 
government also provided many supportive policies to the project). FOXCONN's production base in Chengdu is in operation, and and about $2 / 3$ of the iPads used by consumers throughout the world were produced in this base in 2011. This means that most of these products will be exported to other countries. Undoubtedly, local governments' support to export-oriented industrial investment forms a kind of indirect subsidy to China's exports.

Box 1. A case of Chinese local government actions for attracting investment

In April 2012, SAMSUNG decided to invest a Nand Flash(core processors for iPhone 4S and iPad2) Project in Xi'an, Shanxi Province, China. The total investment is over \$30bn (about RMB200bn), and it will create lots of output value and job opportunities.

What did the local government do to get this project? Why did SAMSUNG decide to build the production base in Xi'an not in other places such as Beijing or Chongqing?

The preferential policies offered by Xi'an municipal government to SAMSUNG are listed as follows::

> Financial subsidies to SAMSUNG: $30 \%$ subsidies of total investment;

$>$ Preferential Income Tax policies: 10 year exemption and 10 year half reduction;

$>$ Required Land and Plant Buildings: Free land; Plant Buildings will be built by the government;

$>$ Auxiliary policies: RMB0.5bn subsidies per year for the cost of water, power, afforesting and logistics; the government will be responsible for highway and metro access to plant.

This decision of Xi'an caused harsh criticism from Chinese people, because it consumes too much public resources on this project. Similar decisions are frequently made in China, because local governments always provide strong support to foreign investors in order to attract investment including FDI.

Take SAMSUNG project as an example, this project will produce core processors of iPhone and iPad. At the same time, FOXCONN (contracted with APPLE INC.) has built a plant in Chengdu, Sichuan Province (produce iPad; total investment was over $\$ 10 \mathrm{bn}$ ), and this plant produced 40 million iPads, about $2 / 3$ of iPads in the world in 2011, and the total number will reach 100 million in 2013. It means that most iPads used by consumers are Made in China, while Chinese cannot buy all of them. So, there is no doubt that such kind of subsidies will indirectly create positive effect on China's export trade.

Sources: Integrated by the author based on Yang \& Lai (2010), Xie (2011) and Zhang \& Du (2012).

Quotas and Certification regulation are also the traditional non-tariff barriers used by Chinese government. China set a Quota \& License Administrative Bureau attached to the Ministry of Commerce to manage trade quotas and licensed affairs, which cover both export and import trade, such as the quotas of raw materials exports and the license of food processing and packaging equipment. Some of China's export restriction by means of quotas and license on material products caused protests from other importing countries. For example, in 2009, the EU, U.S and Mexico appealed to WTO on China's license regulation of some raw materials such as bauxite, coke, spar, magnesium, manganese, silicon metal and zinc, and finally WTO confirmed that these license actions violated the WTO rules. In January 2011, WTO confirmed Chinese quotas and export duties on some raw materials are illegal (EU Commission, 2012).

In addition, China's currency exchange regulation may affect its import and export. The exchange rate system adopted by China is Managed Floating Rate System, which makes it convenient for Chinese government to intervene in exchange market if it is necessary. Owing to governmental control, Renminbi can maintain a high value when it is converted into US dollar, which means the value of Renminbi might be lower than that of other currencies, which will promote export and restrict import. Chinese enterprises and government benefit from the Managed Floating Rate System directly, but it is not conducive to other exporting countries. So, the exchange regulation is always criticized, and other countries have been pressuring Chinese government to deregulate and allow Renminbi appreciate. Transparency is one of the main principles according to WTO provisions. Non-transparency laws and regulations can create trade barriers especially to import. With China's accession to WTO, it has made great efforts to reform and improve its administrative transparency in terms of its commitment to WTO. For example, it has issued a lot of important regulations, established Sanitary and Phytosanitary Measure (SPS) system, and formulated some very important laws and standards (Biuković, 2010). However, research shows that there still exist some non-transparency regulations especially in the sector of industrial 
investment (Kraft, 2010; EU Commission, 2011b, 2012).

In fact, anti-dumping investigation and anti-subsidy investigation can be treated as a kind of non-tariff barrier to trade. Dumping is always created by some supportive policies such as various subsidies and tax exemption which help to reduce the production cost of enterprises. EU's agricultural policies, China's industrial policies and currency exchange regulation make it possible for them to sell their products at a very low price in a foreign market. In response to dumping, both the EU and China start to launch anti-dumping and anti-subsidy investigations in each other's products. If it is verified that a certain product is indeed sold at a dumped price in another market, anti-dumping or anti-subsidy duties will be imposed, which in return becomes tariff barriers. Therefore, anti-dumping and anti-subsidy investigation can be treated as non-tariff barriers too, and by conducting such investigations, a government can give pressure on exporters even though dumping action may not really exist. Moreover, they may also be used as retaliatory measures. For example, EU started its anti-subsidy investigation in coated fine paper imported from China in the early of 2010, and then decided to impose anti-subsidy duties on it on 6 May 2011(EU Council, 2011b). Actually, it is the first time for the EU to impose anti-subsidy duties on Chinese product. In retaliation, on 30 August 2010, China government started the first anti-subsidy investigation in potato starch imported from the EU, and finally decided to impose anti-subsidy duty on it on 16 September 2011. It is worth noting that EU imposes both anti-dumping duty and anti-subsidy duty on the same product. At the beginning, Chinese government argued that the EU violated WTO rules, while finally China government started to impose both anti-dumping and anti-subsidy duties on the same product as well. These interactions indicate that China's action might be a retaliatory response to EU's action. In 2012, the EU launched anti-subsidy investigations in several products imported from China and also caused protest from Chinese government. If the EU finally decides to impose the duties on these products, probably, China will follow suit.

\subsection{Investment Barriers}

Cross-border investment has developed rapidly in the past decades. In order to promote capital flowing across board, developed countries which have a strong advantage in capital, have been making considerable efforts to prevent developing countries from restricting foreign direct investment(FDI). But in fact, many present developed countries are systematically restricting foreign investment to protect domestic industries through various measures, such as limits on ownerships, technology transfer, local procurement, mergers and acquisitions regulations. The developed countries will not lessen their regulation on FDI until the domestic industries get adequately strong and competitive (Chang, 2004). Generally speaking, developing countries have stronger restrictions on foreign investment than developed countries.

However, developed countries still restrict FDI in some sensitive sectors out of the concern for national safety or public interest. EU member states are against some merger and acquisition (M\&A) related to national safety or public interest. In other words, they tend to intervene in FDI market by resorting to the National Security Review Mechanism. For example, on 9 December 2004, France enacted "Law 2004-1343", which states that if foreign investors want to merge or purchase some enterprises of sensitive industries related to public order, public safety, national defense, arms and explosive, they must acquire the authorization of government, and there are corresponding financial penalties for violating relevant regulations. The sensitive sectors include 11 sectors which are listed in Decree 2005-1739, such as gambling and casinos, private security, security of information technology products and systems, cryptology equipment and some sectors related to national defense. In the spring of 2009, Germany enacted the updated Foreign Trade Act, and it empowered Federal Ministry of Economics and Technology right to review and prohibit purchase of domestic companies by foreign investors if the purchase poses threats to public order and security. United Kingdom also apply the National Security Review Mechanism to M\&A of industries related to national safety, media diversity and financial system stability by foreign investors in the light of the "Enterprise Act" launched in 2002 and the explanatory memorandum Order launched in 2008.

Except for National Security Review on M\&A of foreign investors, there are some other restrictions on single sectors in EU member states (GAO, 2008). For example, in France, foreign investment in banking and insurance must be approved by French banking and insurance regulators, and some sectors such as atomic energy, coal mines, and railway passenger transport are not open to FDI. In Germany, inland waterways, employment services, lottery industries are mainly monopolized by public sectors. 
Table 6. Selected foreign investment restriction measures of EU member state and China

\begin{tabular}{|c|c|c|}
\hline Country & Laws and Regulations & Objectives \\
\hline France & Law 2004-1343, Decree 2005-1739 & $\begin{array}{l}\text { public order, public safety, } \\
\text { national defense }\end{array}$ \\
\hline Germany & German Foreign Trade Act 2009 & Public order, public security \\
\hline $\begin{array}{l}\text { Netherland } \\
\mathrm{s}\end{array}$ & Financial Supervision Act 2006 & $\begin{array}{l}\text { Competition, financial market } \\
\text { oversight }\end{array}$ \\
\hline $\begin{array}{l}\text { United } \\
\text { Kingdom }\end{array}$ & Enterprise Act of $2002 \&$ Order 2008 & $\begin{array}{l}\text { Public interest(National Safety, } \\
\text { Media Diversity, Financial } \\
\text { System Stability), control of } \\
\text { classified and sensitive } \\
\text { technology }\end{array}$ \\
\hline China & $\begin{array}{l}\text { Regulations for Mergers and Acquisitions of Domestic } \\
\text { Enterprises by Foreign Investors( } 2009 \text { Revision); } \\
\text { National Security Review System for Mergers and } \\
\text { Acquisitions of Domestic Enterprises by Foreign } \\
\text { Investors(Launched in February 2011); } \\
\text { Catalogue of Industries for Guiding Foreign } \\
\text { Investment (2011 Revision); } \\
\text { Catalogue of Priority Industries for Foreign } \\
\text { Investment in Central and Western China (2008 } \\
\text { Revision) }\end{array}$ & $\begin{array}{l}\text { National economic security; } \\
\text { Protection of critical industries; } \\
\text { Develop local priority } \\
\text { industries; } \\
\text { Purchase of famous trademarks } \\
\text { or traditional Chinese brands; }\end{array}$ \\
\hline
\end{tabular}

Compared with European countries, China exerts much stronger restrictions on FDI. As a developing country, Chinese government tries to protect and boost the development of its domestic industries by offering them supportive policies. For example, Chinese central government laid down the Catalogue of Industries for Guiding Foreign Investment in order to channel foreign capitals and Catalogue of Priority Industries for Foreign Investment in Central and Western China in order to develop competitive industries located in backward regions. According to the current catalogue (2011 revision), only parts of industries are open to foreign investors, and even some of these open industries are restricted. In such industries, foreign investors are only allowed to build joint ventures or cooperative enterprise with Chinese investors. China also established a National Security Review System in February 2011, which states that the M\&A of some industries related to national security, foreign investors cannot be carried out unless they get approval from the central government.

\section{Conclusions and Remarks}

In sum, our research reveals that: the EU and China are each other's main trade partner and the bilateral economic and trade relation are getting much closer; and the close relationship is particularly based on the intra-industrial trade of manufacturing industrial products, especially machinery and transport equipment products. Trade in services and FDI only account for a small part of EU-China economic exchanges. However, from the EU's perspective, the quantity of manufacturing industrial products exported to China is much less than that of the similar products imported from China, which can well explain EU's trade deficit with China. So, if the EU and China want to handle the huge trade deficit, they must improve Composition of Trade to the best of their ability.

This paper also discovers that there still exist a myriad of obstacles to EU-China trade and investment interactions, especially non-tariff obstacles such as various subsidies, trade and investment restrictions, technical barriers and etc. China's market is not open entirely, but protectionism in Europe is also on the rise (Ashton, 2009). Undoubtedly, these barriers are the main factors which lead to EU's huge trade deficit with China. Thus reducing or eliminating trade barriers between EU and China can promote trade development and adjust composition of trade. But to achieve such a goal, it requires joint efforts, mutual trust, frequent interaction and cooperation.

Undoubtedly, the above analysis is just a rough introduction of EU-China economic and trade relations ("Economic Partnership"), and it does not introduce the "Economic Competition" between EU and China. According to the EU commission, the relations between EU and China in both economic field and political field are of both Competition and Partnership (EU Commission, 2006). What should be noted is that this paper just 
focused on the bilateral relations at the supranational level; but in fact, as argued by Dai(2006), relations between the EU and China involves not only bilateral relations at supranational level (EU-China) but also bilateral relations at national level (relation between EU's every member state and China). Thus, if one wants to better understand EU-China economic and trade relations, he/she should also consider the bilateral relations at national level.

\section{Acknowledgments}

This research is supported by the Erasmus + Programme - Jean Monnet Activities (553071-EPP-1-2014-1-CN-EPPJMO-CHAIR), the Fundamental Research Funds for the Central Universities, Sichuan University, China (skgb201405) and the Scientific Research Foundation of Sichcuan University, China (YJ201342).

\section{References}

Ashton, C. (2009). The EU-China Trade Relationship Going Forward: Building Confidence. In Speech at the University of International Business and Economics. Beijing, China.

Beneyto, J. M., Sorroza, A., Hurtado, I., \& Corti, J. (2011). Political Dialogue in EU-China Relations. In Documento de Trabajo Serie Unión Europea (No.50/2011). CEU Ediciones, Madrid, Spain.

Biuković, L. (2010). Selective Adaptation of WTO Transparency Norms and Local Practices in China and Japan. In P. S. Debra (Ed.), Redesigning the World Trade Organization for the Twenty-first Centuy (pp. 193-218). Waterloo, Canada: Wilfrid Laurier University Press.

Brenton, P., Sheehy, J., \& Vancauteren, M. (2001). Technical Barriers to Trade in the European Union: Importance for Accession Countries. Journal of Common Market Studies, 39(2), 265-284.

Brülhart, M., \& Matthews, A. (2007). EU External Trade Policy. In El-Agraa, \& M. Ali (Eds.), The European Union: Economics \& Policies (8th ed., pp. 921-967). Cambridge: Cambridge University Press.

Chang, H.-J. (2004). Regulation of Foreign Investment in Historical Perspective. The European Journal of Development Research, 16(3), 687-715.

Casarini, N. (2006). The Evolution of the EU-China Relationship: from Constructive Engagement to Strategic Partnership. In Occasional Paper (No. 64). Institute for Security Studies, the European Union, Paris, France.

Council of E. C., \& Government of P. R. China. (1985). Agreement on Trade and Economic Cooperation Between European Economic Community and the People's Republic of China. Official Journal of the European Communities, 19 (September), 2-7.

Dai, X. (2006). Understanding EU-China Relations: An Uncertain Partnership in Making. Centre for European Union Studies, The University of Hull, UK.

EU Commission. (1995). A Long-term Policy for China-Europe Relations. In Communication from the Commission. Brussels.

EU Commission. (1998). Building a Comprehensive Partnership with China. In Communication from the Commission. Brussels.

EU Commission. (2001). EU Strategy towards China: Implementation of the 1998 Communication and Future Steps for a more Effective EU Policy. In Communication from the Commission. Brussels.

EU Commission. (2003). A Maturing Partnership-Shared Interests and Challenges in EU-China Relations. In Commission Policy Paper. Brussels.

EU Commission. (2006). Closer Partners, Growing Responsibilities, A Policy Paper On EU-China Trade and Investment: Competition and Partnership. In Commission Working Document. Brussels.

EU Commission. (2010). The CAP towards 2020: Meeting the Food, Natural Resources and Territorial Challenges of the Future. In Communication from the Commission. Brussels.

EU Commission. (2011a). Commission Regulation (EU) No 258/2011 of 16 March 2011 Imposing a Provisional Anti-dumping Duty on Imports of Ceramic Tiles Originating in the People's Republic of China. Official Journal of the European Union (English Edition), 54(17), 5-30.

EU Commission. (2011b). Trade and Investment Barriers Report 2012. In Report from the Commission to the European Council. Brussels. 
EU Commission. (2012). Trade and Investment Barriers Report 2012. In Report from the Commission to the European Council. Brussels.

EU Council. (2000a). Council Regulation (EC) No 1334/2000 of 22 June 2000 Setting up a Community Regime for the Control of Exports of Dual-use Items and Technology. Official Journal of the European Union(English Edition), 54(30), 1-215.

EU Council. (2000b).Council Decision of 22 June 2000 Repealing Decision 94/942/CFSP on the Joint Action Concerning the Control of Exports of Dual-use Goods. Official Journal of the European Union (English Edition), 54(30), 218.

EU Council. (2000c). Council Joint Action of 22 June 2000 Concerning the Control of Technical Assistance Related to Certain Military End-uses. Official Journal of the European Union (English Edition), 54(30), 216-217.

EU Council. (2011a). Council Implementing Regulation (EU) No 917/2011 of 12 September 2011 Imposing a Definitive Anti-dumping Duty and Collecting Definitively the Provisional Duty Imposed on Imports of Ceramic Tiles Originating in the People's Republic of China. Official Journal of the European Union (English Edition), 54(15), 1-23.

EU Council. (2011b). Council Implementing Regulation (EU) No 451/2011 of 6 May 2011 Imposing a Definitive Anti-Subsidy Duty on Imports of Coated Fine Paper Originating in the People's Republic of China. Official Journal of the European Union (English Edition), 54(14), 18-75.

EU Council. (2011c). Council Implementing Regulation (EU) No 452/2011 of 6 May 2011 Imposing a Definitive Anti-Dumping Duty and Collecting Definitively the Provisional Duty Imposed on Imports of Coated Fine Paper Originating in the People's Republic of China. Official Journal of the European Union (English Edition), 54(14), 1-17.

EUROPA. (2007). EU Budget-Facts and Myths. Press Releases.

Fox, J., \& Godement, F. (2009). A Power Audit of EU-China Relations. European Council on Foreign Relations(ECFR), London, UK.

GAO. (2008). Laws and Policies Regulating Foreign Investment in 10 Countries. Highlights of GAO-08-320, a report to the Honorable Richard Shelby, Ranking Member, Committee on Banking, Housing, and Urban Affairs, U.S. Senate. U.S. Government Accountability Office, Washington DC.

Global Britain. (2004). Customs Duties: Hardly Worth Collecting. Global Britain Briefing Note. London, UK.

Griese, O. (2006). EU-China Relations-An Assessment by the Communications of the European Union. Asia Europe Journal, 4(4), 544-554.

Kasteng, J. (2012). Paving the Way for Unfair Competition: The Imposition of EU Anti-Dumping Duties on Ceramic Tiles from China. Stockholm, Sweden: National Board of Trade.

Kern, S. (2008). SWFs and Foreign Investment Policies-An Update. Frankfurt. German: Deutsche Bank Research.

Kraft, J. M. (2010). Surviving the "Made in China" Stigma: Challenges for Chinese Multinational Corporations (Master of Arts Thesis). California, USA: University of Southern California.

Lardy, N. R. (2003). Trade Liberalization and Its Role in Chinese Economic Growth. Proceedings of International Monetary Fund and National Council of Applied Economic Research Conference. New Delhi, India.

Lorca-Susino, M. (2006). The EU-China Trading-Economic Relationship is not a Zero-Sum Game. European Union Miami Analysis (EUMA), 3(3).

Mullally, L., O’Brien, N., \& Stephenson, P. (2005). Open Up: Why the EU Must Reform to Survive. London, UK: Open Europe.

National Audit Office. (2008). Financial Management in the European Union. Norwich, UK: The Stationery Office.

Prevost, D., Choukroune, L., Creemers, R., \& Huchet, J.-F. (2011). EU-China Trade Relations. Directorate-General for External Policies of the Union, Directorate B, European Parliament, Brussels, Belgium.

SCIO. (2011). China's Foreign Trade. Governmental White Paper (1st ed.). State Council Information Office 
(SCIO), Beijing, China.

Smith, M., \& Xie, H. (2010). The European Union and China: The Logics of 'Strategy Partnership'. Journal of Contemporary European Research, 6(4), 432-448.

Sorroza, A. (2011). Is the Eurozone Crisis Changing EU-China Relations? In Elcano Royal Institute (ARI). Madrid, Spain.

Stepan, M., \& Ostermann, F. (2011).EU-China Relations: Strategic or Pragmatic, the Future or Already the Past? Atlantisch Perspectief, 35(2), 19-24.

Van der Putten, F. P. (2009). The EU Arms Embargo against China: Should Europe Play a Role in East Asian Security? In Social and Cultural Research Occasional Paper Series (No.7). Centre for Qualitative Social Research Centre, Department of Sociology, Hong Kong Shue Yan University, Hong Kong, China \& East Asian Studies Program, Department of History, Pace University, New York, USA.

Von Reppert-Bismarck, J. (2004). OECD Scolds EU, U.S. for Slow Farm-Subsidy Cuts. The Wall Street Journal Europe.

Wickman, K. (2003). Whither the European Agricultural Policy? A Viable Reform of the CAP in the Context of an Enlarged EU and the Doha Development Round. Stockholm, Sweden: Timbro.

Xie, Y. (2011). Two-thirds of iPad in the Word Will be made in Chengdu within the Year. Chengdu Economic Daily, p. A41. Retrieved from http://e.chengdu.cn/html/2011-02/16/content_213682.htm

Yang, X., \& Lai, F. (2010). Products of FOXCONN (Chengdu Base) Passed the Export Clearance Test. Huaxi Metropolis Daily, p. A8. Retrieved from http://www.wccdaily.com.cn /epaper/hxdsb/html/2010-10/19/content_245059.htm

Zhang, Y., \& Du, Y. (2012). The Dowry of SUMSUNG Landing Xi'an. The Economic Observer, p. A13. Retrieved from http://epaper.eeo.com.cn/shtml/jjgcb/20120416/76721.shtml

\section{Notes}

Note 1. Trade between EU and China grew slowly in the latter half of the 1980s due to the political instability.

Note 2. Data in this paragraph is from European Communities. (2002). External and Intra-European Union Trade-Statistical Yearbook: Data 1958-2001 (pp. 30-31). Luxembourg: Office for Official Publications of the European Communities.

Note 3. Actually, in July, 1995, European Commission published its first Communication "A Long-term Policy for China-Europe Relations" which made a detail policy framework and measures involving all dimensions such as political, trade, investment, economic cooperation, science and technology cooperation, and so on(EU Commission, 1995). Moreover, the agreement on scientific and technological cooperation of EU-China was signed in the end of this year.

Note 4. Proportion of China's FDI composition in this paragraph are calculated by the author based on the data from Ministry of Commerce of China. (2010). China Commercial Yearbook 2010. Beijing: China Commerce and Trade Press. 


\section{Appendix A}

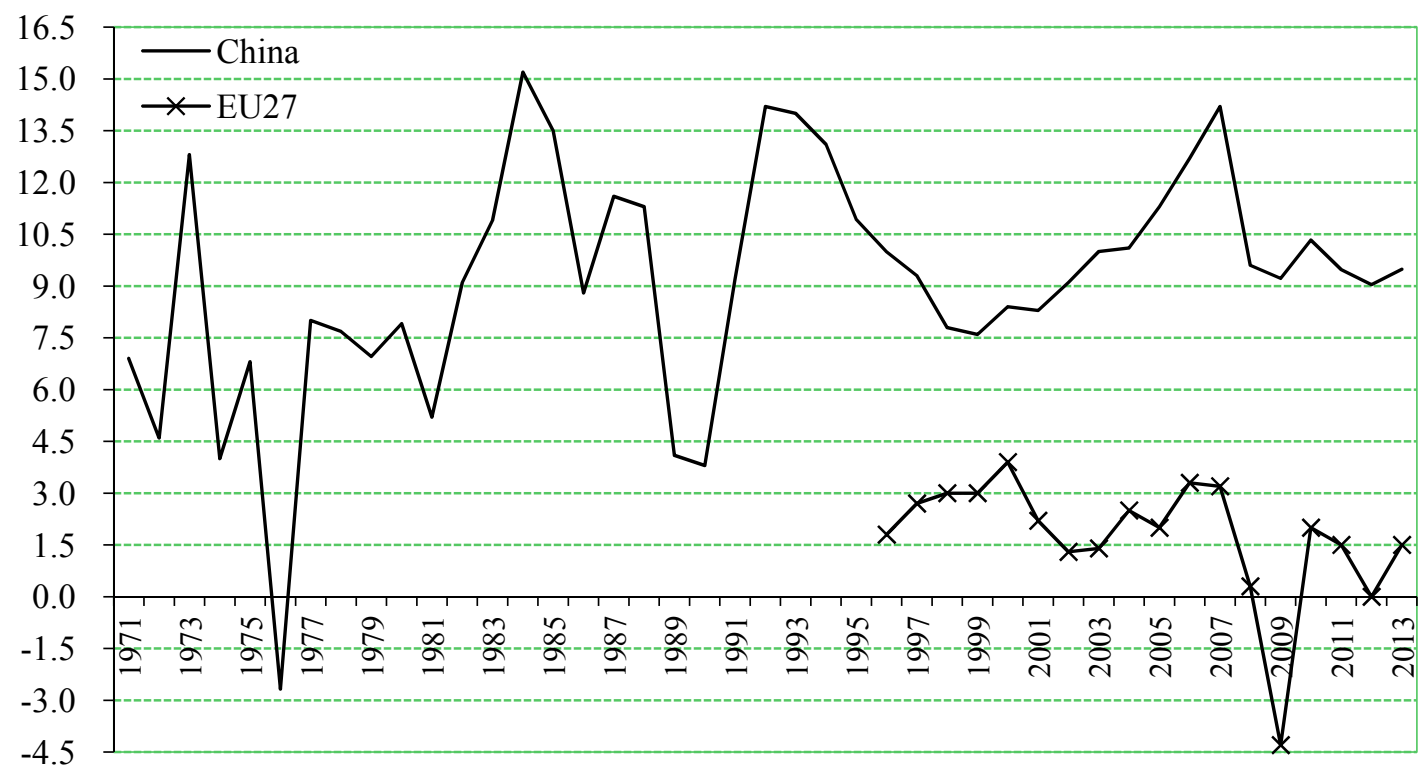

Figure A1. Real GDP growth rate of China and EU (1971-2013)

Notes. Forecasted Value From 2011 to 2013.

Sources: China's real GDP growth rate data are from World Economic Outlook (WEO) Data provided by IMF; EU's real GDP growth rate data is from Eurostat.

Table A1. Industrial structure of EU \& China external trade in goods

\begin{tabular}{llllllc}
\hline & \multicolumn{4}{c}{ EU27 } & \multicolumn{3}{c}{ China } \\
\cline { 2 - 7 } \multicolumn{1}{c}{ Industries(SITC) } & 4 & 4.1 & 4.9 & 4.9 & 2.71 & 1.47 \\
\cline { 2 - 7 } & 2000 & 2010 & 2000 & 2010 & 2009 & 2009 \\
\hline Food and live animals & 1.6 & 1.6 & 0.6 & 0.5 & 0.14 & 0.19 \\
Beverages and tobacco & 1.8 & 2.6 & 4.7 & 4.3 & 0.68 & 14.00 \\
Crude materials, except fuels & 3.4 & 5.6 & 16.2 & 25.4 & 1.70 & 12.33 \\
Energy products & 0.3 & 0.2 & 0.3 & 0.4 & 0.03 & 0.76 \\
Oil, fats and waxes & 14.0 & 17.4 & 7.1 & 9.1 & 5.16 & 11.15 \\
Chemicals & 14.3 & 12.8 & 11.2 & 10.5 & 15.38 & 10.71 \\
Manufactured goods classified by material & 46.3 & 42.4 & 37.4 & 29.5 & 49.13 & 40.57 \\
Machinery and transport equipment & 12.1 & 10.4 & 14.0 & 13.6 & 24.94 & 8.47 \\
Miscellaneous manufactured articles & 2.4 & 2.9 & 1.6 & 1.9 & 0.14 & 0.33 \\
Products not classified elsewhere & Chyyyyyyy \\
\hline
\end{tabular}

Source: EU Trade Yearbook 2011(EUSTAT, 2011); China Commercial Yearbook (Ministry of Commerce of China, 2010). 
Table A2. EU Products of which China is one of the top10 trade partners (2010, Million Euro, \%)

\begin{tabular}{|c|c|c|c|c|c|c|c|c|}
\hline & \multirow[b]{2}{*}{ Industrial Classification } & \multicolumn{3}{|c|}{ Exports to China } & \multicolumn{3}{|c|}{ Imports from China } & \multirow[b]{2}{*}{ Balance } \\
\hline & & Value & Share & $\begin{array}{l}\text { China's } \\
\text { Rank }\end{array}$ & Value & Share & $\begin{array}{l}\text { China's } \\
\text { Rank }\end{array}$ & \\
\hline \multirow{6}{*}{ Foods Products } & $\begin{array}{l}\text { Miscellaneous edible products and } \\
\text { preparations }\end{array}$ & 364 & 4.8 & 5 & NT & NT & NT & \multirow{10}{*}{-26} \\
\hline & Beverages & 808 & 4.4 & 7 & NT & NT & NT & \\
\hline & Fish, crustaceans, mollusks & NT & NT & NT & 1,526 & 8.9 & 2 & \\
\hline & Vegetables and fruit & NT & NT & NT & 1,440 & 6.9 & 3 & \\
\hline & Feeding stuff for animals & NT & NT & NT & 130 & 1.5 & 6 & \\
\hline & Oil seeds and oleaginous fruits & NT & NT & NT & 255 & 3.9 & 7 & \\
\hline \multirow{4}{*}{ Raw Materials } & Cork and wood & 248 & 5.9 & 7 & 274 & 5.4 & 5 & \\
\hline & Textile fibers and their wastes & 396 & 13.3 & 2 & NT & NT & NT & \\
\hline & Crude fertilizers & 4024 & 29.4 & 1 & NT & NT & NT & \\
\hline & $\begin{array}{l}\text { Crude animal and vegetable materials, } \\
\text { n.e.s. }\end{array}$ & 236 & 5.8 & 4 & NT & NT & NT & \\
\hline Fuel Products. & Coal, coke and briquettes & NT & NT & NT & 112 & 0.7 & 9 & \multirow{3}{*}{-1223} \\
\hline \multirow{4}{*}{ Chemicals } & Organic chemicals & 2618 & 6.1 & 4 & 3841 & 11.6 & 3 & \\
\hline & Inorganic chemicals & NT & NT & NT & 1052 & 8.9 & 3 & \\
\hline & Medicinal and pharmaceutical products & 2944 & 3.1 & 7 & 2463 & 5.1 & 3 & 481 \\
\hline & Plastics in primary forms & 2722 & 12.1 & 2 & 440 & 3.8 & 7 & 2282 \\
\hline \multirow{9}{*}{$\begin{array}{l}\text { Machinery and } \\
\text { Equipment }\end{array}$} & Chemical materials and products, n.e.s. & 1555 & 6.8 & 3 & NT & NT & NT & \\
\hline & $\begin{array}{l}\text { Power generating machinery and } \\
\text { equipment }\end{array}$ & 5806 & 9.5 & 2 & 2823 & 8.1 & 3 & 2983 \\
\hline & Machinery specialized for particular ind. & 10289 & 14.4 & 1 & 2270 & 13.5 & 4 & 8019 \\
\hline & $\begin{array}{l}\text { General industry machinery and } \\
\text { equipment }\end{array}$ & 11935 & 13.2 & 2 & 9620 & 26.9 & 1 & 2315 \\
\hline & Telecommunication, sound, TV, video & 1740 & 4.7 & 7 & 37510 & 50.1 & 1 & -35770 \\
\hline & Office machines and computers & 1073 & 4.5 & 8 & 40280 & 54.2 & 1 & -39207 \\
\hline & of which computer equipment & 311 & 2.7 & 10 & 27676 & 70 & 1 & -27365 \\
\hline & Electrical machinery & 10699 & 12.9 & 2 & 40062 & 38.5 & 1 & -29363 \\
\hline & of which valves, transistors etc. & 2002 & 13.4 & 2 & 16691 & 38.5 & 1 & -14689 \\
\hline \multirow{4}{*}{$\begin{array}{l}\text { Transport } \\
\text { Equipment }\end{array}$} & Road vehicles & 17552 & 13.7 & 2 & 3873 & 8.3 & 4 & 13679 \\
\hline & of which passenger cars etc. & 12184 & 16 & 2 & 482 & 2.2 & 8 & 11702 \\
\hline & Aircraft, spacecraft etc. & 5012 & 11.9 & 2 & 119 & 0.4 & 7 & 4893 \\
\hline & Ships, boats etc. & NT & NT & NT & 7555 & 33.3 & 1 & \\
\hline & Textile yarn, fabrics and related products & NT & NT & NT & 6602 & 32.5 & 1 & \\
\hline \multirow{8}{*}{$\begin{array}{l}\text { Other } \\
\text { Manufactured } \\
\text { Goods }\end{array}$} & Paper, paperboard and articles thereof & 724 & 3.7 & 6 & NT & NT & NT & \\
\hline & Non-metallic mineral manufactures & 1355 & 4.3 & 7 & 5007 & 19.9 & 1 & -3652 \\
\hline & Iron and steel & 1992 & 5.7 & 4 & 3150 & 12 & 3 & -1158 \\
\hline & Non-ferrous metals & 2437 & 12.2 & 2 & 1737 & 4.7 & 7 & 700 \\
\hline & Manufactures of metals & 2191 & 6.7 & 4 & 10743 & 41.3 & 1 & -8552 \\
\hline & Clothing and clothing accessories & 407 & 2.4 & 10 & 30513 & 45.6 & 1 & -30106 \\
\hline & $\begin{array}{l}\text { Professional, scientific, controlling } \\
\text { material }\end{array}$ & 4216 & 10.5 & 2 & 3015 & 10.2 & 3 & 1201 \\
\hline & Miscellaneous manufactured articles & 1712 & 3.6 & 6 & 25092 & 45.1 & 1 & -23380 \\
\hline
\end{tabular}

Notes. NT represents that China is not one of the top 10 partners of EU; Sources: EU Trade Yearbook 2011(EUSTAT, 2011).

\section{Copyrights}

Copyright for this article is retained by the author(s), with first publication rights granted to the journal.

This is an open-access article distributed under the terms and conditions of the Creative Commons Attribution license (http://creativecommons.org/licenses/by/3.0/). 